\title{
Impact of Fill Factor on Input Current Ripple of PV System
}

\author{
Ahmad H. El Khateb \\ Electrical-Electronics Engineering \\ Department \\ Zirve University \\ Gaziantep, Turkey \\ ahmad.elkhateb@zirve.edu.tr
}

\author{
Nasrudin Abd Rahim \\ UM Power Energy Dedicated \\ Advanced Centre \\ University of Malaya \\ Kuala Lumpur, Malaysia \\ nasrudin@um.edu.my
}

\author{
Barry W. Williams \\ Electronic \& Electrical Engineering. \\ Strathclyde University \\ Glasgow, Scotland, G1 1XW, UK \\ barry.williams@strath.ac.uk
}

\begin{abstract}
This paper discusses the impact of fill factor on the input current ripple of the photovoltaic module and the loss effect on power extracted. Photovoltaic module's P-V curve produces exponential curve. The curvature of this curve indicates the fill factor of the particular cell, hence, by increasing the fill factor, the available extracted power increases. Yet, this paper states that losses due to photovoltaic current increases by increasing the fill factor.
\end{abstract}

\section{Keywords—input current ripple; photovoltaic cell; fill factor}

\section{INTRODUCTION}

The ripple of photovoltaic current has a notable influence when connected with switching mode power supply [1]. The perfect power supply does not reproduce ripple on the input current. Normally, power supplies are not perfect because the resistance of input produces rippled voltage and current curves at what time the input power has ripple [2], [3]. The photovoltaic source can be both a current and voltage source. The photovoltaic array is a dynamic source of energy that has dc output voltage. Fig. 1 shows the influence of the voltage and current ripple on the power curve, where a weighty loss of power as the ripple rises. The photovoltaic cell characteristics change owing to the radiation and temperature, which decrease the average power hence increase the losses [4]. As ripple current raises the effective point transfers to the region of constant voltage on the photovoltaic characteristic curve, which outcomes in a sharp decline in the power. The nonlinear characteristics of photovoltaic panel curve obstruct the clear calculation of fill factor (FF) which is a main pointer of the photovoltaic panel performance. The fill factor is defined by the maximum power divided by the multiplication of the maximum voltage and the maximum current. For higher fill factor, the decline of the power curve becomes sharper and hence more power losses. By increasing the mean power, the operating point transfers to the point of maximum power and the ripple decreases to zero.

\section{ANALYSIS AND PROBLEM DEMONSTRATION}

If current ripple exist, maximum dc power cannot be achieved by achieving maximum power using any tracking algorithm [5], [6]. For zero-ripple, the maximum power can be

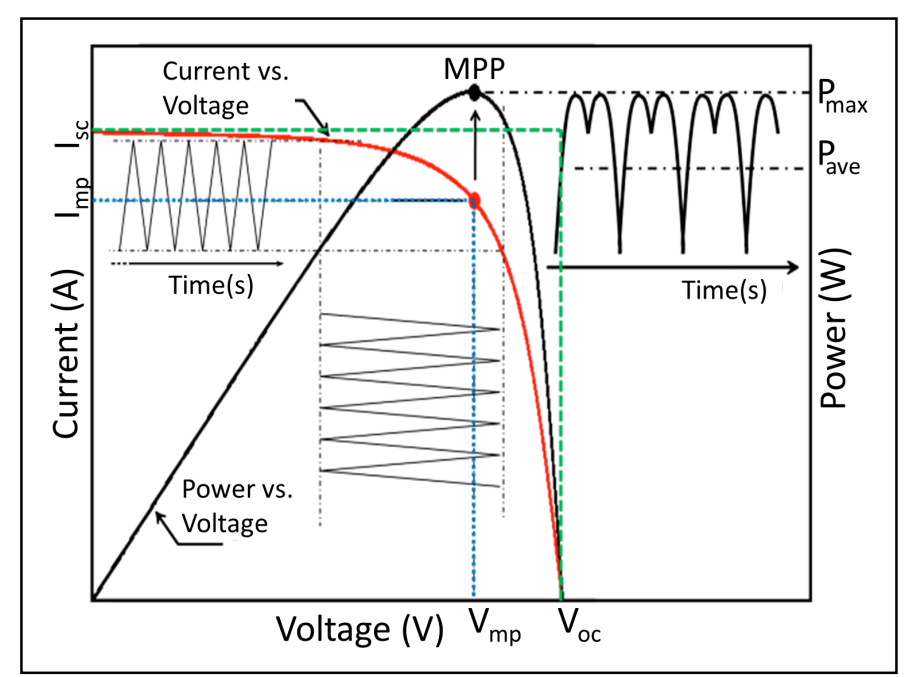

achieved since the PV cell maximum power point can be tracked.

Fig. 1: Impact of input current ripple on the PV power curve

For calculation the expression of the ripple current, an exponential diode model of photovoltaic panel with identical cells is used.

$$
v(t)=m V_{T} \ln \left(\frac{I_{s c}-i(t)}{I_{s}}+1\right)
$$

where $i(t)$ is the panel current, $v(t)$ is the panel voltage, $m$ is the number of cells, $I_{s c}$ is the short-circuit current, $I_{s}$ is scale current, and $V_{T}$ is thermal voltage.

The output power can be transcribed in terms of current

$$
P(t)=i(t) m V_{T} \ln \left(\frac{I_{s c}-i(t)}{I_{s}}+1\right)
$$

The power of any effective point, $\left(V_{x}, I_{x}\right)$, can be expanded using Taylor series as follows:

$$
p(t)=V_{x} I_{x}+\Delta i(t) \frac{d P}{d i}+\frac{1}{2} \Delta i(t)^{2} \frac{d^{2} P}{d i^{2}}
$$

The power at maximum power point can be expressed as:

$$
p(t)=V_{m p p} I_{m p p}+\frac{1}{2} \Delta i(t)^{2} \frac{d^{2} P}{d i^{2}}
$$


The mean power reduction can be stated in terms of rippled voltage rms value as follow:

$$
P_{\text {ripple }}=-\frac{1}{2}\left(\Delta i_{r m s}\right)^{2} \frac{d^{2} P}{d i^{2}}
$$

From (2), the first and second derivative of power can be derived in terms of current as in (6) and (7):

$$
\begin{aligned}
& \frac{d P}{d i}=m V_{T} i(t)\left(\frac{-1}{I_{s}+I_{s c}-i(t)}\right)+m V_{T} \ln \left(\frac{I_{s}+I_{s c}-i(t)}{I_{s}}\right) \\
& \frac{d^{2} P}{d i^{2}}=\left(\frac{-2 m V_{T}}{I_{s}+I_{s c}-i(t)}\right)-\left(\frac{m V_{T} i(t)}{\left(i(t)-I_{s}-I_{s c}\right)^{2}}\right) \\
& \text { at maximum power point: } \\
& V_{m p p}=\left(\frac{m V_{T} I_{m p p}}{I_{s}+I_{s c}-I_{m p p}}\right)=m V_{T} \ln \left(\frac{I_{s}+I_{s c}-I_{m p p}}{I_{s}}\right) m V_{T} \\
& \frac{V_{m p p}}{I_{m p p}}=\frac{m V_{T}}{I_{s}+I_{s c}-I_{m p p}}
\end{aligned}
$$

The second derivative can be concluded by substituting (9) in (7).

$$
\frac{d^{2} P}{d i^{2}}=-2 \frac{m V_{T}}{I_{s}+I_{s c}-I_{m p p}}-\frac{\left(\frac{m V_{T}}{I_{s}+I_{s c}-I_{m p p}}\right)^{2} I_{m p p}}{m V_{T}}
$$

The power ripple can be defined by substituting (10) and (9) in (5):

$$
P_{\text {ripple }}=\left(\Delta i_{r m s}\right)^{2}\left[\frac{m V_{T}}{I_{s}+I_{s c}-I_{m p p}}+\frac{V_{m p p}^{2}}{2 m V_{T} I_{m p p}}\right]
$$

The rippled power can be expressed in terms of the current ripple and the fill factor as follows:

$$
\frac{P_{\text {ripple }}}{P_{m p p}}=F F\left(\frac{\Delta i_{r m s}}{I_{m p p}}\right)^{2}\left[\frac{I_{s c}\left(m V_{T} / V_{m p p}+1 / 2\right) \ln \left(I_{s c} / I_{s}+1\right)}{I_{s c}+I_{s}\left(1-e^{V_{m p p} / m V_{T}}\right)}\right]
$$

Where $F F=V_{m p p} I_{m p p} / V_{o c} I_{s c}$.

For typical values $V_{m p p}=0.5 \mathrm{~V}, I_{s c}=0.5 \mathrm{~A}, I_{s}=1 e-10$ per cell, and $V_{T}=25.85 \mathrm{mV}$, (15) can be written as follows:

$$
\frac{P_{\text {ripple }}}{P_{m p p}} \approx 13\left(\frac{\Delta i_{r m s}}{I_{m p p}}\right)^{2} F F
$$

Current ripple with an rms value equals to $7 \%$ of the maximum power point current and 0.65 fill factor would result in a $4.1 \%$ reduction in power output and with one fill factor would result in a $6.37 \%$ power output reduction. Therefore, by enhancing the fill factor the losses due to ripple current increases.

At the maximum power point, with incompatibilities in irradiation or PV cell characteristics, the IV curve becomes sharper. The sharp curving characteristic increases the input current ripple influence. Consider a string of $\mathrm{N}$ parallel $\mathrm{PV}$ cells without any bypass diode. Under full irradiation level, if all cells have an open-circuit voltage $\mathrm{V}_{\text {oc }}$, but one cell is shaded with $0.5 \mathrm{~V}_{\text {oc }}$ open-circuit voltage, then, all cells operate at most $0.5 \mathrm{~V}_{\mathrm{oc}}$. Thus, the cells work close to their short-circuit current, and can be considered as current sources. The voltage of the maximum power point will be near $0.5 \mathrm{~V}_{\text {oc }}$ because, as voltage of the cells tends to $0.5 \mathrm{~V}_{\mathrm{oc}}$, the current does not drop sharply. Only the one shaded cell current changes significantly. Hence, the current variation range for a significant voltage variation is changed by a ratio approximately equivalent to the ratio of the number of unshaded cells to the number of shaded cells which is N. Therefore, the effect of input ripple current can be increased by $\mathrm{N}$ compared to the unshaded cells case.

\section{RESULTS}

The MPPT converter works at the mean current value, which is identical to photovoltaic MPP of the ripple-free current. At such circumstance, the power curve has repeated minor and major power slopes, as shown in Fig. 2, which result in converter power losses. Fig. 2 shows the curves of the power at different ripple values starting from $5 \%$ to $90 \%$ of its short circuit current, providing the mean efficiencies and power values in Table $\mathrm{I}$, at $25^{\circ} \mathrm{C}$ and $1000 \mathrm{~W} / \mathrm{m}^{2}$. Therefore, the mean maximum power point is unlike the free rippled point since the ripple diverges from the operating point according to the mean rippled power curve.

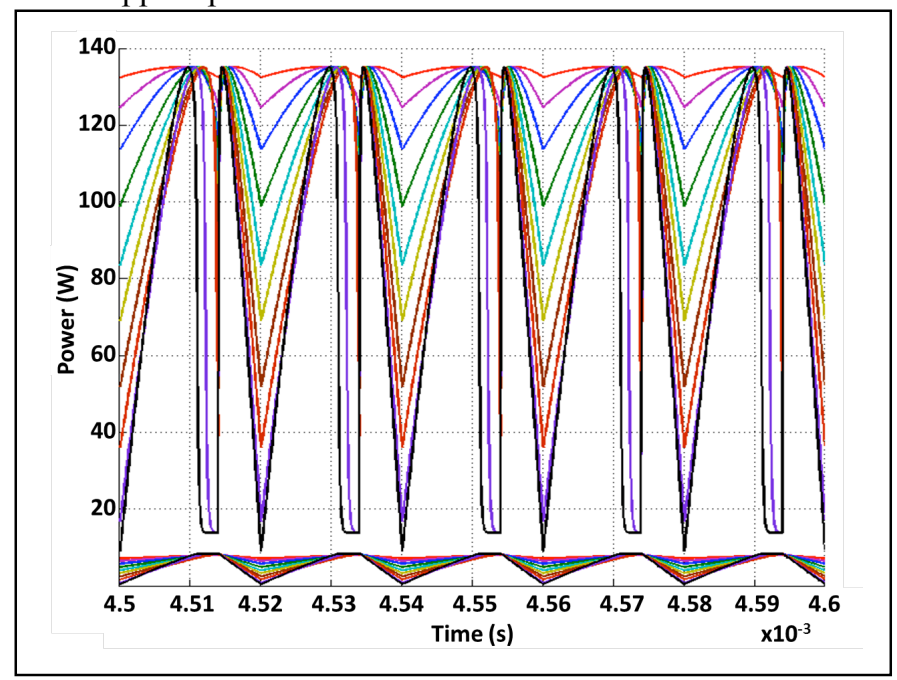

Fig. 2: Input ripple effect and PV input power

Ripple current influence rises by reducing the crowning of the power curve. Since the input current relies on the topology of the converter and the crowning of the power-voltage curve relies on the level of irradiance. Therefore, reducing the irradiance or working on low current raises the ratio of the input current ripple along with power losses.

TABLE I. INPUT CURRENT RIPPLE VS. PV EFFICIENCY

\begin{tabular}{|c|c|c|c|c|c|c|c|c|c|c|}
\hline$\% \mathrm{I}_{\mathrm{sc}}$ & 5 & 10 & 20 & 30 & 40 & 50 & 60 & 70 & 80 & 90 \\
\hline $\mathrm{P}_{\mathrm{ave}}$ & 132.3 & 129.9 & 127.6 & 122.2 & 116.2 & 110.3 & 103.3 & 96.7 & 74.7 & 41.4 \\
\hline $\mathrm{PV} \eta \%$ & 97.3 & 95.5 & 93.8 & 89.8 & 85.5 & 81.1 & 76.0 & 71.1 & 54.9 & 30.4 \\
\hline
\end{tabular}

Simulation is presented in Fig. 3 showing the impact of the ripple. The switching frequency used is $50 \mathrm{kHz}$ with a Kyocera KD135GX-LP PV panel $\left(\mathrm{V}_{\mathrm{OC}}=22.1 \mathrm{~V}, \mathrm{I}_{\mathrm{SC}}=8.37 \mathrm{~A}, \mathrm{~V}_{\mathrm{MP}}=17.7 \mathrm{~V}\right.$, $\left.\mathrm{I}_{\mathrm{MP}}=7.63 \mathrm{~A}, \mathrm{P}_{\mathrm{MAX}}=135 \mathrm{~W}, \mathrm{FF}=0.733\right)$. The figure is for stated test conditions, $\left(\delta=0.3\right.$ to 0.9 duty cycle, $G=800 \mathrm{~W} / \mathrm{m}^{2}$ radiation, 1 to $\mathrm{I}_{\mathrm{MAX}} \mathrm{A}$ input current).

The PV efficiency is the power transfer ratio between the terminals of the dc-to-dc converter and the PV panel while the efficiency of the dc-to-dc converter is the power transfer ratio on the converter output excluding converter losses like copper losses. Therefore, the combination between the PV efficiency 
and the dc-to-dc converter efficiency produces the overall efficiency of the whole system.

The experiment results in Fig. 4 show the input current ripple at maximum power point current and the overall efficiency at $1000 \mathrm{~W} / \mathrm{m}^{2}$. Impact of the low ripple current on dc-to-dc converter clearly exhibited on the overall efficiency. The test has been applied on three different converters with different input current ripple. The converter with lowest input current has the highest PV efficiency. In the same way, by reducing the duty cycle and the input current, the overall efficiency of the system rises. Furthermore, by increasing the fill factor, the available extracted power increases, therefore, losses due to photovoltaic current increases by increasing the fill factor.

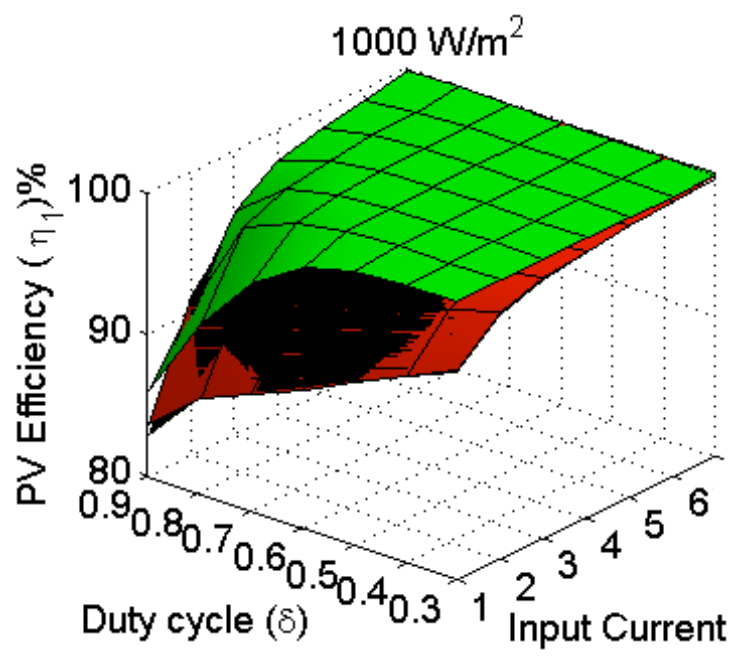

(a)

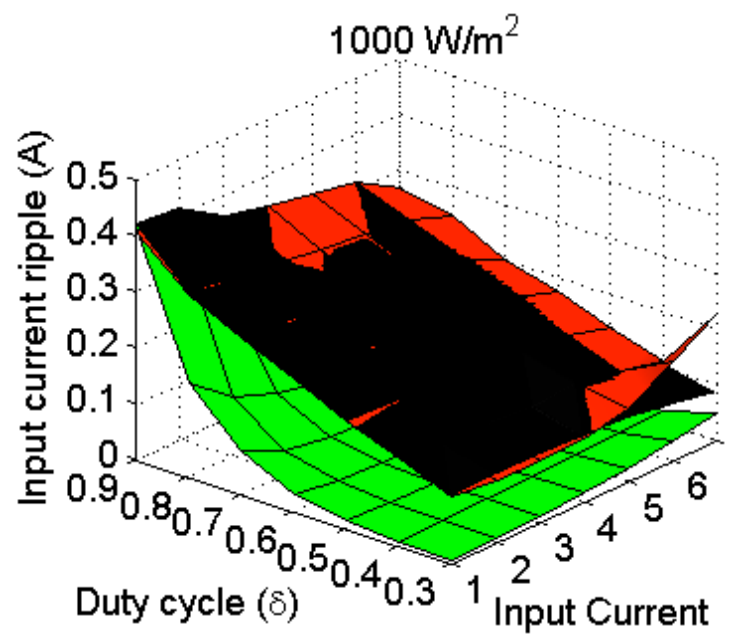

(b)

Fig. 3 Simulation of three different input rippled current effect (a) PV efficiency, (b) Input ripple current

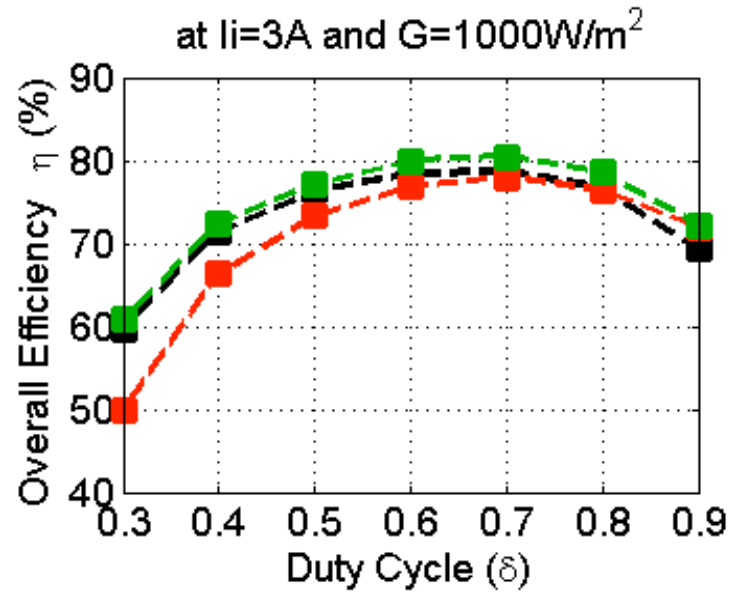

(a)

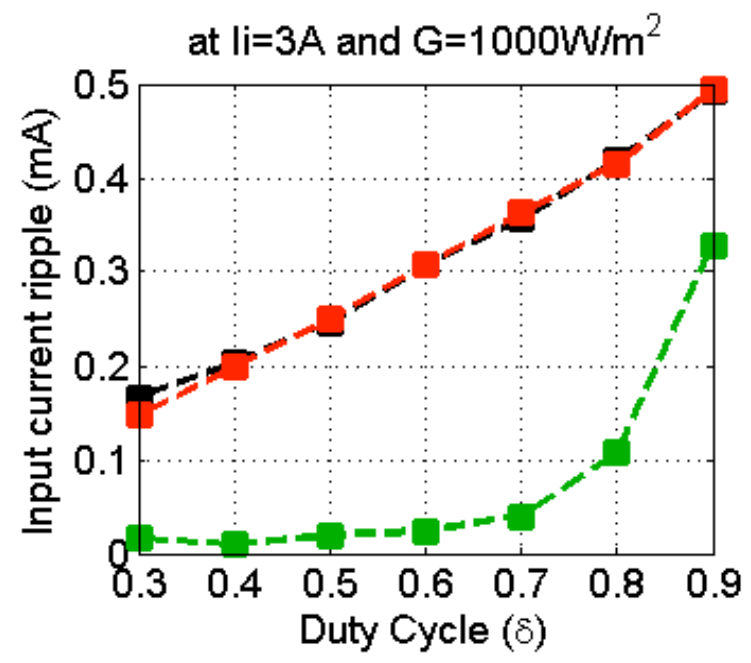

(b)

Fig. 4 Practical test results for three different converters (a) Overall efficiency, (b) Input ripple current

\section{CONCLUSION}

In this paper, the impact of the input current ripple on the photovoltaic panel efficiency has been studied. The effect of the current ripple on the photovoltaic panel and the loss of power extracted have been considered, together with converter efficiency, thus losses in the overall system efficiency. The efficiency degrading impact of the input current ripple on the photovoltaic panel has been established. Mathematical derivation has authenticated the effect of the fill factor of the PV panel together with the ripple existence. Results showed that the overall efficiency of the PV system can be improved by decreasing the input ripple current as well as the fill factor. 


\section{REFERENCES}

[1] H. Do, "Improved ZVS DC-DC Converter with a High Voltage Gain and a Ripple-Free Input Current," IEEE Trans. Circuits Syst., vol. 59, no. 4, pp. 846-853, Apr. 2012.

[2] J. Lee, and B. Kwon, "Active-Clamped Ripple-Free DC/DC Converter Using an Input-Output Coupled Inductor," IEEE Trans. Ind. Electron., vol. 55, no. 4, pp. 1842-1854, Apr. 2008.

[3] Y. Chen, Y. Liu, and F. Wu, "Multiinput converter with power factor correction, maximum power point tracking, and ripple-free input currents," IEEE Trans. Power Electron., vol. 19, no. 3, pp. 631-639, May 2004.

[4] El Khateb, A.; Rahim, N.A.; Selvaraj, J.; Williams, B.W., "The effect of input current ripple on the photovoltaic panel efficiency," Clean Energy and Technology (CEAT), 2013 IEEE Conference on, 18-20 Nov. 2013.

[5] A. El Khateb, N. Rahim, J. Selvaraj, and M. Uddin, "Fuzzy-LogicController-Based SEPIC Converter for Maximum Power Point Tracking," IEEE Trans. Ind. Appl., vol. 50, no. 4, pp. 2349-2358, JulyAug. 2014.

[6] El Khateb, A.; Rahim, N.A.; Selvaraj, J.; Uddin, M.N., "Maximum power point tracking of single-ended primary-inductor converter employing a novel optimisation technique for proportional-integralderivative controller," Power Electronics, IET, vol. 6, no. 6, pp. 11111121, July 2013. 